\title{
Is benthic food web structure related to diversity of marine macrobenthic communities?
}

\author{
A. Sokołowski ${ }^{a, *}$, M. Wołowicz ${ }^{a}$, H. Asmus ${ }^{b}$, R. Asmus ${ }^{b}$, A. Carlier ${ }^{c}$, Z. Gasiunaitéd ${ }^{d}$ A. Grémare ${ }^{e}$, \\ H. Hummel ${ }^{f}$, J. Lesutiené ${ }^{d}, A$. Razinkovas $^{d}$, P.E. Renaud ${ }^{g}$, P. Richard ${ }^{h}$, M. Kędra ${ }^{i}$
}

\footnotetext{
a University of Gdańsk, Institute of Oceanography, Al. Piłsudskiego 46, 81-378 Gdynia, Poland

b Alfred-Wegener-Institut für Polar- und Meeresforschung, Wattenmeerstation Sylt, Hafenstr. 43, 25992 List, Germany

c IFREMER, DYNECO - Ecologie Benthique, Technopole Brest-Iroise, BP70, 29280 Plouzané, France

d University of Klaipeda, Coastal Research and Planning Institute, H.Manto 84, LT 92294, Klaipeda, Lithuania

e UMR 5805 EPOC - OASU Station Marine d'Arcachon, Université Bordeaux 1, 2 Rue du Professeur Jolyet, 33120 Arcachon Cedex, France

${ }^{f}$ Netherlands Institute of Ecology, Centre for Estuarine and Marine Ecology, Korringaweg 7, 4401 NT Yerseke, The Netherlands

${ }^{g}$ Akvaplan-niva AS, Fram Centre for Climate and Environment, N-9296 Troms $\emptyset$, Norway

${ }^{\mathrm{h}}$ Littoral, Environnement et Sociétés, UMR 6250 CNRS-Université de La Rochelle, Bât. Marie Curie, Avenue Michel Crépeau, 17042 La Rochelle, France

i Institute of Oceanology, Polish Academy of Sciences, ul. Powstańców Warszawy 55, 81-712 Sopot, Poland
}

\author{
*: Corresponding author: A. Sokolowski, tel: + 48585236856 ; fax: + 48585236678 ; \\ email address : oceas@univ.gda.pl
}

\begin{abstract}
:
Numerical structure and the organisation of food webs within macrozoobenthic communities has been assessed in the European waters (Svalbard, Barents Sea, Baltic Sea, North Sea, Atlantic Ocean and the Mediterranean Sea) to address the interactions between biodiversity and ecosystem functioning. Abundance and classical species diversity indices $\left(S, H^{\prime}, J\right)$ of macrofaunal communities were related to principal attributes of food webs (relative trophic level and food chain length, $F C L$ ) that were determined from carbon and nitrogen stable isotope values. Structure of marine macrobenthos varies substantially at a geographical scale; total abundance ranges from 63 ind. $\mathrm{m}^{-2}$ to 34,517 ind. $\mathrm{m}^{-2}$, species richness varies from 3 to 166 and the Shannon-Weaver diversity index from 0.26 to 3.26 while Pielou's evenness index is below 0.73 . The major source of energy for macrobenthic communities is suspended particulate organic matter, consisting of phytoplankton and detrital particles, sediment particulate organic matter, and microphytobenthos in varying proportions. These food sources support the presence of suspension- and deposit-feeding communities, which dominate numerically on the sea floor. Benthic food webs include usually four to five trophic levels ( $F C L$ varies from 3.08 to 4.86). Most species are assigned to the second trophic level (primary consumers), fewer species are grouped in the third trophic level (secondary consumers), and benthic top predators are the least numerous. Most species cluster primarily at the lowest trophic level that is consistent with the typical organization of pyramidal food webs. Food chain length increases with biodiversity, highlighting a positive effect of more complex community structure on food web organisation. In more diverse benthic communities, energy is transferred through more trophic levels while species-poor communities sustain a shorter food chain.
\end{abstract}

Keywords : macrobenthic communities ; Biodiversity ; food web structure ; diversity-structure interactions ; European waters 


\section{Introduction}

Interactions between biodiversity and ecosystem functioning in marine systems have attracted considerable attention for many years. Understanding the potential link of structural features of faunal communities and their functionality can provide clues to the assessment of threats to ecosystem state, productivity and services to humans due to biodiversity changes induced by climate change and anthropogenic activities. This study addresses biodiversityfunctioning linkages by comparing benthic food web structure in marine and coastal ecosystems of a different biodiversity level and with diverse physical or human constraints at a pan-European scale. Ecosystem processes integrate the interactions between organisms and both the environment and each other, and biodiversity mediates these interactions (Heip et al., 1998). Diversity of habitats and species varies geographically across environmental and ecological gradients, structuring ecosystems and their functioning at local and global scales. Ecosystem metabolism is intimately linked to carbon and nitrogen fluxes from primary producers to consumers of higher trophic levels. This trophic transfer determines the productivity of ecosystems depending on the structure and efficiency of the food webs. Systems with high diversity and complex trophic interrelations such as the Mediterranean Sea or the Atlantic Ocean are considered to be stable and productive (Loreau, 2000), while in systems such as the Baltic Sea average diversity is low and food web structure relatively simple (Sokołowski, 2009). Despite such striking differences in their structures, the productivity of the food web in the Baltic is reported to be similar to that of the Atlantic (Elmgren and Hill, 1995) which contrasts the early "productivity hypothesis" of Elton (1927) assuming that more productive ecosystems have longer food chains. This would indicate that high biodiversity might not be an essential prerequisite for stable or highly productive ecosystems. However, the number of trophic interactions between species increases with a concomitant increase in species number, as do the number of material cycles and pathways within a food web. Other hypotheses argue that food chain length should increase with increasing ecosystem size and community organisation (Vander Zanden et al., 1999; Post et al., 2000) and that food webs with longer food-chain lengths might be more susceptible to shortening by disturbance (Jenkins et al., 1992). Furthermore, according to Post (2000) in isolated or evolutionarily young systems food web structure can be strongly influenced by colonisation history. Some evidence exists also that energy or resource availability at the base of food web and energetic efficiency of organisms within a food web (trophic efficiency) increase the complexity of food web and food chain length (Yodzis, 1984; Jenkins et al., 
1 composition in explaining variation in food web structure has been debated in scientific

2 community for long time, only limited progress has been made in understanding the 3 relationship between biodiversity and trophic web organisation in natural ecological systems.

4 Therefore the question arises; to what extent food web structure in an ecosystem (e.g. seagrass bed, mussel bed, subtidal sand, mudflats, etc.) is related to the diversity of the species pool.

To address this question, a large-scale comparative study was performed on the structure of food webs in macrobenthic systems that differ in the magnitude and complexity of species assemblages in different European marine and coastal waters. By relating data on basic food web principles with selected species diversity indices and total macrobenthic abundance, possible linkages between food web organisation and taxonomic diversity were unravelled.

\section{Material and methods}

\subsection{Study sites}

Data on taxonomic structure and carbon and nitrogen stable isotope ratios of macrobenthic fauna were obtained through original studies of the authors (own data) or other researchers and by conducting literature searches using available scientific databases such as ISI Web of Knowledge. Eight locations were selected to represent a range of environmental and ecological systems (e.g. the presence of tides, salinity gradients, shallow- and deep-water regions, the presence of macroplants) covering a suite of habitats from the European Arctic in the North (Spitsbergen and Barents Sea) through the Baltic Sea (Curonian Lagoon and the Gulf of Gdańsk), North Sea (Sylt-Rømø Bight and Westerschelde), the Atlantic coast of France (Marennes-Oleron Bay), to the Mediterranean Sea (Bay of Banyuls-sur-Mer) (Fig. 1, Table 1). In addition, at locations of high habitat diversity, two sites differing in environmental conditions and a structure of macrobenthic communities were chosen. Out of a total of 13 sites, five are BIOMARE project (Implementation and Networking of large-scale long-term Marine Biodiversity research in Europe) biodiversity sites (Warwick et al., 2003).

Fig. 1 and Table 1 here

\subsection{Benthic community structure}

Benthic communities were considered as the faunal (>1mm) organisms inhabiting the top $10 \mathrm{~cm}$ of surficial sediments or epiphytic taxa living on the surface of bottom substratum. Special care was taken to use data from samples taken with quantitative gears (Van Veen grab 
1 community structure parameters (Eleftheriou and McIntyre, 2005). In order to reduce

2 variations in community structure due to temporal alterations of environmental variables and ecophysiological traits of organisms, data referring to spring or summer were extracted from the databases for most of the sites (Table 2). Since protists were not considered at the majority of sites, they were excluded from the analysis. On the basis of the collected data from direct field investigations or literature (Table 2), species richness ( $S$, a total number of species per sample) and total macrobenthic abundance were calculated to provide descriptive statistics of benthic communities. In systems where predatory birds or mammals are considered to be the top predators, they were excluded from the analysis due to the lack of available data and to maintain consistency throughout the study. Taxonomic nomenclatures used followed the European Register of Marine Species (http://www.marbef.org/data/erms.php) and http://www.itis.gov. The diversity of macrobenthic communities was estimated using the Shannon-Weaver diversity index $H^{\prime}$ (Shannon and Weaver, 1963) while evenness was determined using the Pielou's $J$ (Pielou, 1966).

\subsection{Organisation of food webs}

In order to define the organisation of macrobenthic food webs, data on stable isotopes of carbon $\left({ }^{13} \mathrm{C} /{ }^{12} \mathrm{C}\right)$ and nitrogen $\left({ }^{15} \mathrm{~N} /{ }^{14} \mathrm{~N}\right)$ in non-living organic and living components of each ecosystem were incorporated into the analyses. Because of the convincing presence of seasonal effects on isotope ratios (Martinez del Rio, 2007), only data collected in spring and summer were used. At most sites the isotope stable-isotope data were taken from literature while two sites, namely Hornsund and Brouage, were sampled in 2009 for the purpose of this study (Table 3). The samples were analysed for carbon and nitrogen stable isotope ratios following a routine procedure (Boutton, 1991). In brief, suspended particulate organic matter on Whatman GF/F filters (glass microfibre filters; $0.7 \mu \mathrm{m}$ ), $<63 \mu \mathrm{m}$ fraction of surficial sediments $(0-5 \mathrm{~cm})$, macrophytes and soft tissue of benthic animals were frozen, freeze-dried, homogenised and acidified with $1 \mathrm{M} \mathrm{HCl}$ overnight when necessary. Benthic organisms were grouped into three pools containing at least three, but for most species more, individuals in order to obtain a representative sample. $\delta^{13} \mathrm{C}$ and $\delta^{15} \mathrm{~N}$ were determined using an Isoprime Micromass IRMS-EA (EUROVECTOR CHN analyser coupled with MICROMASS mass spectrometer) and the data obtained were expressed in the standard $\delta$ unit notation (\%o). The composition of carbon isotopes has long been used as a tracer of food sources in marine and estuarine ecosystems (Hecky and Hesslein, 1995) while nitrogen isotope ratios indicate the 
1 ratios were employed to estimate the relative trophic level (RTL) of a consumer in the food web, using the model developed by Hobson and Welch (1992):

$$
R T L=\left(\delta^{15} N_{\text {consumer }}-\delta^{15} N_{\text {baseline }}\right) / 3.4+2,
$$

where $\delta^{15} \mathrm{~N}_{\text {consumer }}$ is the nitrogen isotope ratio of a consumer, $\delta^{15} \mathrm{~N}_{\text {baseline }}$ is the nitrogen isotope baseline of the primary consumer, 3.4 is the assumed ${ }^{15} \mathrm{~N}$ trophic enrichment factor (Post, 2002; Olive et al., 2003). Primary consumers have been agreed to provide an appropriate baseline signal since they show lower temporal variability than organic matter sources (Post, 2002; Vander Zanden and Fetzer, 2007). Due to possible among-site variations

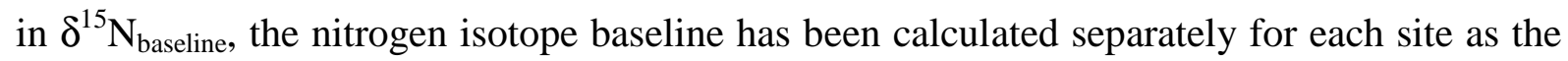
mean $\delta^{15} \mathrm{~N}$ of all primary consumers (Vander Zanden and Fetzer, 2007). The formula is a simplified modification of the food web model of Post (2002) and allows for the contribution of various organic matter sources in a diet of consumers, but rather gives rough estimates since the weighting of each consumer, and thus its diet, is equal. However, such a model has been successfully employed to define trophic levels of different species or groups of organisms in marine, coastal and freshwater systems (Hobson et al., 1995; Vander Zanden et al., 1999; Fredriksen, 2003; Grall et al., 2006). A RTL between 2 and 3 indicates the second trophic level (primary consumers and omnivores) while RTLs $>3$ indicate consumers with carnivorous diets (secondary, tertiary and higher level consumers).

Using carbon and nitrogen natural isotopes, the following principal attributes of food web were determined separately at each site: (1) the source of organic matter fuelling benthic biocenosis, (2) the relative trophic level (RTL) of each consumer species and (3) total food chain length (FCL). The FCL has been employed following a definition of Duffy et al. (2007) i.e. the average number of steps that energy is transferred as it moves from base resources to top predators.

The origin of organic matter was assessed using carbon isotope ratios of all potential carbon sources in a given system, including suspended particulate organic matter (SPOM), sediment organic matter (SOM), microphytobenthos (bulk sample) and macrophytobenthos. In addition, at the Barents Sea locations SPOM bound to ice was incorporated into analyses as an important carbon source in the Arctic (Tamelander et al., 2006). Food chain length was defined as the trophic position of the top predator i.e. taxon with the highest $\delta^{15} \mathrm{~N}$ value (Vander Zanden and Fetzer, 2007): 


$$
F C L=\left(\operatorname{Max} \delta^{15} N_{\text {consumer }}-\delta^{15} N_{\text {baseline }}\right) / 3.4+2,
$$

$F C L$ is thus a measure of energy transfers (trophic levels) from the base to the top of the food web that integrates the assimilation of energy or mass flow through all the trophic pathways (Post, 2002). Functional relationships between pairs of variables, i.e. species richness, total macrobenthic abundance, diversity and evenness indices vs. FCL were assessed with regression analysis (Kendall's robust line-fit method). The significance of source type, sampling site and location on $\delta^{13} \mathrm{C}$ and $\delta^{15} \mathrm{~N}$ was evaluated by analysis of variance (ANOVA) proceeded by analysis of normality (the Kolmogorov-Smirnov test for goodness of fit) and homogeneity of variances. The level of significance for all tests was set as $p<0.05$ (Sokal and Rohlf, 1995). Statistical analyses were carried out using STATISTICA 8.1 (StatSoft, Inc., 1997).

\section{Results}

\subsection{Macrobenthic community structure}

A total of 499 faunal species were identified representing 33 classes. Polychaeta with totally 183 species was the most represented class, followed by Crustacea (110 species), Bivalvia (75 species) and Gastropoda (30 species). At two sites Curonian-mb and Curonianbs, located in the Curonian Lagoon, Clitellata was the most numerous class, containing five and four species, respectively. Species richness $(S)$ ranged from three at site Gdansk to 166 in the Barents Sea. At most sites the taxonomic diversity was dominated by polychaetes which constituted from 33.3\% (Gdansk) up to $44.5 \%$ (Banyuls) of the total number of macrofaunal species. Exceptions were found at the Baltic sites: at Puck Bay with a predominant role of bivalves (36.4\%), Curonian-mb - gastropods (20.7\%) and at Curonian-bs where equal contributions of $17.4 \%$ were observed for bivalves, crustaceans and clitellates, respectively. Taxonomic diversity was also highly variable, with the Shannon-Weaver diversity index varying from 0.26 at site Oleron Zostera-up on the Atlantic coast of France to 3.26 at site St 4 in the Barents Sea. Evenness was not high with Pielou's index calculated to below 0.74 for all sites with the lowest value of 0.08 observed at site Oleron Zostera-uf (Tab. 2).

High among-site variability was also clear for the total abundance of macrobenthic fauna which ranged from 63 ind. $\mathrm{m}^{-2}$ at site Gdansk to 71704 ind. $\mathrm{m}^{-2}$ at site Sylt-Rømø. In contrast 
to the pattern of geographic variation in distribution of faunal species among classes, molluscs were the most abundant group at eight sites (gastropods at five sites and bivalves at three sites) comprising up to $96.2 \%$ of the total macrobenthic abundance followed by polychaetes (four sites) with a percentage contribution of $85.8 \%$ (Fig. 2).

\section{Fig. 2 here}

\subsection{Stable nitrogen and carbon isotope ratios}

\subsubsection{Organic matter sources}

Five ecosystem components were considered the potential food sources to primary consumers across all sampling sites i.e. sediment organic matter/detritus (SOM), suspended particulate organic matter (SPOM) which include iceSPOM and phytoplankton, microphytobenthos (bulk sample), macroalgae regrouped into nine genera (i.e. Cladophora, Fucus, Ulva, Ceramium, Gracilaria, Porphyra, Laminaria, Chorda, Acrosiphonia) and vascular plants representing five genera (i.e. Zostera, Potamogeton, Spartina, Salicornia, Posidonia). These organic carbon sources differed statistically in isotope carbon ratios $\left(\delta^{13} \mathrm{C}\right.$ spanning a range of $22.9 \%$ for all sites; ANOVA, $F_{4,46}=18.92, P<0.001$ ) but not in stable nitrogen ratios ( $\delta^{15} \mathrm{~N}$ spanning a range of $8.7 \%$ for all sites) (Fig. 3). Regardless of geographic position and environmental/biocenotic conditions, the most depleted of $\delta^{13} \mathrm{C}$ was SPOM (from $-28.5 \%$ to $-21.8 \%$ ) with clearly lowered values of riverine suspended particulate organic matter (down to $-33.3 \%$ at site Curonian-mb) that can be distinguished from local marine SPOM. Increased $\delta^{13} \mathrm{C}$ was noticed for iceSPOM i.e. $-21.7 \%$ and $-20.0 \%$ at sites St 4 and St 16 in the Barents Sea, respectively. Macroalgae and microphytobenthos demonstrated relatively enriched carbon isotope ratios varying from $-21.8 \%$ to $-13.2 \%$ and from $-15.7 \%$ to $14.4 \%$, respectively. The isotope composition of SOM fell within a range of $-24.7 \%$ to $20.1 \%$ which reflects a combination of SPOM and phytal material in varying percentages depending on the proximity of the two sources, and presumably also intense microbial decomposition of sedimented organic material. Vascular plants had the most enriched carbon isotope ratios from $-15.1 \%$ to $-8.4 \%$ at all sites, with the exception of the common glasswort, Salicornia sp. at site Sylt-Røm $\varnothing$ where $\delta^{13} \mathrm{C}$ was low at about $-28.6 \%$ (Fig. 3).

\section{Fig. 3 here}

The combined data on $\delta^{13} \mathrm{C}$ and $\delta^{15} \mathrm{~N}$ revealed dual sources of organic matter to macrobenthic communities at a site. The principal carbon source of the food webs comprised 
1 Puck, Gdansk, Curonian-mb, Curonian-bs, Sylt-Rømø, Molenplaat, Banyuls, and St 16 and

2 Hornsund. At sites St 4 and St 16 in the Barents Sea iceSPOM appeared an important food source to consumers on a local scale. In very shallow euphotic areas of dense benthic vegetation (sites Oleron Zostera-uf and Oleron Zostera-lf) macroalgae and vascular plants can contribute substantially to the organic matter pool which is exploited by benthic fauna. In some instances however, $\delta^{13} \mathrm{C}$ and $\delta^{15} \mathrm{~N}$ of benthic invertebrates cannot be linked to any carbon sources analysed (e.g. insects and gastropods at site Curonian-bs, ophiuroids and holothurians at St 4), suggesting the complex utilisation of other sources of organic matter (e.g. decaying detritus, products of anaerobic metabolism of chemoautotrophic bacteria) which may form separate trophic pathways.

\section{Fig. 4 and Table 3 here}

\subsubsection{Trophic positions of benthic consumers and food chain length}

A total of 327 macrobenthic faunal species regrouped into 30 classes were analysed for stable isotope composition, representing from $17.4 \%$ (at site Curonian-bs) to $66.7 \%$ (at site Puck), and from $47.1 \%$ (at site Curonian-bs) to $98.9 \%$ (at site Brouage) of species richness and the total abundance at a given site, respectively. Low percentage contributions of species number and abundance, that were measured for stable isotopes, occurred at the two sites St 4 and St 16 in the Barents Sea. This results from the presence of numerous small-sized macrobenthic organisms of an even distribution and low individual dry weight (mainly Crustacea, Polychaeta and Malacostraca) which provided insufficient material for isotope analyses. Nevertheless, the sampling effort can be considered satisfactory since it covered a wide array of macrobenthic species in each water-basin. The number of taxa that were analysed per site varied from three at the site Gdansk to 121 at Banyuls (Table 3).

The carbon and nitrogen isotope composition of benthic macrofauna spanned a wide range around the average of $20.4 \%$ (from $-30.1 \%$ for freshwater leech Helobdella stagnalis in the brackish Baltic Sea to $\mathbf{- 9 . 7 \%}$ or for Idotea chelipes on the Atlantic coast of France) and 19.8\%o (from $2.7 \%$ o for the bivalve Gari depressa in the Mediterranean Sea to $22.5 \%$ o for the predatory polychaete Eteone in the North Sea) for $\delta^{13} \mathrm{C}$ and $\delta^{15} \mathrm{~N}$, respectively. Stable isotope ratios showed apparent geographic variations among locations $\left(A N O V A, F_{6,399}=110.07, P<\right.$ $0.001)$ and sites $\left(A N O V A, F_{12,399}=74.72, P<0.001\right)$, reflecting spatial differences in organic matter sources across sampling sites, but it can also indicate different feeding strategies among species. Variation in $\delta^{13} \mathrm{C}$ and $\delta^{15} \mathrm{~N}$ also differed among dominating systematic groups within each site. The $\delta^{13} \mathrm{C}$ ratio spanned the widest range for bivalves and crustaceans that 
1 implies a broad food spectrum of these animals and reflects among-site differences in $\delta^{13} \mathrm{C}$ of

2 carbon sources. In contrast, bivalves and gastropods demonstrated the least variable $\delta^{15} \mathrm{~N}$ as 3 they represent primary consumers feeding mainly on SPOM (suspension-feeders) and 4 epiphytic microalgae (herbivores), respectively. The exception was site Banyuls where predatory gastropods of the genus Nassarius had a $\delta^{15} \mathrm{~N}$ up to $9.7 \%$.

The number of primary consumer species at a site ranged from two (Gdansk) to 36 (Banyuls) and was usually $>7$ species at the vast majority of sites. The calculated site-specific nitrogen isotope baseline ranged from $2.7 \%$ at site Banyuls up to $16.9 \%$ at site Molenplaat. Food chain length $(F C L)$ spanned at least three trophic levels and varied from 3.08 at the Baltic site Gdansk up to 4.86 at site Curonian-mb (Table 3). Primary consumers (RTL between 2.0 and 3.0) included mainly bivalves (filter-feeders), herbivorous gastropods, crustaceans and polychaetes of mixed diet. At the majority of sites, secondary consumers (RTL between 3.0 and 4.0) were comprised of larger predators, namely infaunal and epifaunal crustaceans, polychaetes and fish. At site Banyuls in the Mediterranean Sea this trophic level included also numerous carnivorous gastropods while at sites St 4 and St 16 in the Barents Sea asteroids were abundant. Fish and asteroid species occupied the highest trophic position of RTL >4.0. The number of species in subsequent trophic levels generally decreased with trophic position (Fig. 5), shaping the hierarchical structure of the trophic pyramid. Most species were assigned to the second level, fewer species were in the third trophic level, and benthic top predators were the least numerous or even contained no species.

Fig. 5 here

\subsubsection{Relation between biodiversity and food web principles}

Relationships between total abundance of macrobenthos, species richness $(S)$ and the calculated diversity indices ( $H^{\prime}$ and $J$ ) and $F C L$ were determined, using the correlation coefficient at the confidence level of $95 \%$, to assess potential links between the composition of macrobenthic communities and food web structure. Food chain length was positively correlated with species richness $\left(F C L=0.007 S+3.702, R^{2}=0.48, P<0.009, \mathrm{n}=13\right)$ and the Shannon-Weaver diversity index $\left(F C L=0.606 H^{\prime}+3.092, R^{2}=0.78, P<0.001, \mathrm{n}=13\right)$.

\section{Discussion}


Large-scale studies of macrobenthic communities revealed substantial differences in 2 abundance and biodiversity level of the marine macrobenthos in European waters. The lowest 3 species richness (3-29) and density (63-5015 ind. $\mathrm{m}^{-2}$ ) were observed in the non-tidal Baltic 4 Sea where low salinity (6.0-8.0), eutrophication and locally adverse oxygen conditions strongly affect the number of benthic faunal taxa (Wolowicz et al., 2007; Renaud et al., 2009). Another explanation includes the relatively young age of the Baltic which has been slowly colonized by freshwater and marine organisms since the complete deglaciation only 8000 years ago (Bonsdorff, 2006). Larger numbers of taxa (27-32) and higher abundance of macrobenthos (7152-15701 ind. $\mathrm{m}^{-2}$ ) were noted in the fully-saline tidal flats of the North Sea and the French Atlantic coast that are located between $45^{\circ} \mathrm{N}$ and $54^{\circ} \mathrm{N}$. A similar number of species in the coastal zone of intermediate latitudes was also reported in extensive studies of diversity patterns of benthic shelf invertebrates by Renaud et al. (2009). Benthic assemblages at two open-water deep Arctic sites in the Barents Sea demonstrated the highest species richness (166), which fits well the pattern of increasing diversity with depth and towards the pole. As the hypothesis on the increase of marine benthic biodiversity toward a pole has not been fully confirmed (e.g. Włodarska-Kowalczuk et al., 2007; Renaud et al. 2006), the species richness has been convincingly proved to follow unimodal trends with water depth and a maximum at 180-220 $\mathrm{m}$ water depths (Renaud et al., 2009). Exceptionally high numbers of benthic species (128) were shown at the most southern site Banyuls which is located in the Bay of Banyuls-sur-Mer, a small open bay in the southwest of the Gulf of Lions, France (northwestern Mediterranean Sea).

\subsection{Organisation of food webs - use of primary organic matter sources}

Irrespective of geographic location, the major sources of energy to macrobenthic communities appeared to originate from suspended particulate organic matter, comprising phytoplankton and detrital particles of floral and faunal origin (SPOM) in varying proportions, and sediment organic matter (SOM). The significance of SPOM and SOM as the main food source for macrobenthos can be also indicated by the dominance of suspensionand deposit-feeding taxa including bivalves, gastropods (Mollusca) and polychaetes (Annelida) over herbivorous taxa at the majority of sites (Fig. 2). These taxonomic groups are hypothesized to contribute substantially to benthic-pelagic coupling, and also providing the main energy transfer pathway within the benthic biocenoses. The dominating trophic role of SPOM and planktonic production has also been noted in isotope investigations of benthic 
1 (Kaehler et al., 2000), and in the Marennes-Oléron Bay (Riera, 1998). In the open waters of

2 the Barents Sea, but not in the Arctic fjord of Spitsbergen, iceSPOM which shows enriched

$3 \delta^{13} \mathrm{C}$ and $\delta^{15} \mathrm{~N}$ values relative to SPOM (Tamelander et al., 2006), provides energy to benthic

4 invertebrates. In addition, on sandy and muddy tidal flats of the North Sea and the French

5 Atlantic coast, autochthonous sources of organic matter include microphytobenthos (Monbet, 1992). Epipelic diatoms have apparently a distinct carbon isotope composition from SPOM and SOM that derives from their weaker discrimination against ${ }^{13} \mathrm{CO}_{2}$ due to relative lower access to atmospheric $\mathrm{CO}_{2}$ as it is in the water column for plankton algae. Benthic macroalgae and vascular plants can be neglected as a potential carbon source in benthic food webs. Even in the shallow-water euphotic areas of dense vegetation, only small groups of invertebrates (some gastropods and crustaceans) had an isotope signature consistent with those of the benthic macroalgae and vascular plants after trophic enrichment. Therefore, these supplementary trophic links do not to support additional energy pathways to higher trophic levels. A large part of macrophytal primary production probably supplies the sediment organic matter pool which fuels secondary production via the detritus food chain.

\subsection{Vertical structure of food webs - food chain length}

The calculated site-specific nitrogen isotope baseline fell within a range of ca. from $6.0 \%$ o to $9.4 \%$ at the majority of sites, except at Banyuls and Molenplaat where it was $2.7 \%$ and $16.9 \%$, respectively. The carbon and nitrogen stable isotope ratios of consumers generally reflect the isotope composition of their food sources in a particular area with the known increment factors (Ostrom and Fry, 1993). The similarity in $\delta^{13} \mathrm{C}$ and $\delta^{15} \mathrm{~N}$ between animals and plants from the same habitat was documented as early as in the first isotope studies of the marine environment (Craig, 1953; Parker, 1964) and was further evidenced by a number of later studies in various aquatic systems (e.g. Créach et al., 1997; Riera et al., 1999; Fredriksen, 2003). The shift in $\delta^{13} \mathrm{C}$ and $\delta^{15} \mathrm{~N}$ between a consumer and its food is the principal and basic assumption in all ecological studies that aim at assessing trophic pathways in any faunal community (Martinez del Rio, 2007). Close relationships in the carbon and nitrogen composition of organic matter sources and animals also allows distinguishing different populations that rely on isotopically divergent sources at local and larger scales. However, recent reviews indicate that the fractionation of $\delta^{15} \mathrm{~N}$ might be affected by multiple factors such as taxonomic position, the physiological condition of an animal (e.g. starvation), the nitrogen contents of the food and the consumer (specifically protein and amino acid 
1 concentrations), growth efficiency and ontogenic state (Vander Zanden and Rasmussen, 2001;

2 McCutchan Jr. et al., 2003; Vanderklift and Ponsard, 2003).

Food chain length varied from 3.08 to 4.86 (Table 3) but these values might be underestimated due to the absence of migrating aquatic birds and marine mammals as top predators whose introduction into analyses can increase the $F C L$ on average by 0.64 (Vander Zanden and Fetzer, 2007). The observed range of FCL is consistent with FCL estimates for estuarine, coastal and marine systems reported by Vander Zanden and Fetzer (2007), and generally agrees with classical food web theory, which states that food chains are usually limited to a maximum of three or four trophic levels in aquatic systems (Cohen et al., 1986; Briand and Cohen, 1987). Hastings and Conrad (1979) argued that the evolutionary stable length of a food chain would be three, and that the main determinant of the number of trophic levels is the quality of the organic matter energy sources (e.g. the C:nutrient ratio) and not their quantity, as is often suggested in discussions of food chain length. Omnivory may be a compromise between exploiting large quantities of low quality resources (at a low metabolic cost) and exploiting lesser quantities of high-quality food (at a high metabolic cost). Benthic omnivorous organisms can thus avoid nutrient deficiency (due to lower nutritional values of phytal and detrital materials of high C:nutrient ratio) through their access to a large reservoir of energy (Elser and Hessen, 2005). This feeding strategy has developed in the benthic fauna in different European waters. However, due to uneven sampling effort (differences in detailed species sampling) and the species-specific dynamics of isotope incorporation, the delineated species distribution among trophic levels (Fig. 5) provides only a rough proxy of hierarchical food web patterns. It cannot be excluded either that the observed FCLs could also be affected by ecosystem size (Vander Zanden and Fetzer, 2007) and the degree of environmental perturbations (Pimm, 1982).

\subsection{Diversity of benthic communities vs. food chain length}

Regression analyses of selected variables of macrobenthic communities and food web attributes revealed a positive correlation of species richness $(S)$ and Shannon-Weaver diversity index $\left(H^{\prime}\right)$ with food chain length. It is noteworthy that the relation $H^{\prime}-F C L$ was stronger than the relation $S-F C L$, highlighting differences between the effect of the total number of species and of dominants (so called keystone species) on food web architecture. Since $H^{\prime}$ is biased toward the more dominant species which certainly participate more in the energy transfer (because of higher abundance and biomass) and the more rare community members (so called week interactors) contribute little to the Shannon-Weaver diversity index, 
1 the $H^{\prime}-F C L$ relationship indicates strong trophic links of keystone taxa and their importance 2 in food web shaping. This finding contrasts with models accounting for differences in 3 interaction strength which imply that weak interactors play a crucial role by decreasing variations between consumers and resources and thus contribute to maintaining food web complexity and enhancing community stability (Benedetti-Cecchi., 2000).

Food chain length increases with biodiversity, indicating to the possible positive effect of community diversity and abundance on the number of links in the food chain from basal to top predatory species. High species number induces high functional complexity of the communities, where some functional groups (based on, for example, feeding type or mobility) are represented by many species, resulting in diverse cycles of energy and matter. In more diverse benthic assemblages energy is transferred through more trophic pathways which contain more species. Consequently, a larger number of species contained within different trophic levels implies more complex trophic interactions, increasing the stability of the food web - defined as the ability to withstand temporal variability/perturbations in a system. According to the stability-complexity theory, a high number of species and the resultant higher trophic connectance have a stabilizing effect on the ecosystem (MacArthur, 1955). Conversely, less diverse communities based on a small number of species (e.g. in habitats subject to disturbances, for example on oxygen-deficient bottom of the southern Baltic) sustain a simple food web structure with weak and rare interactions. Such communities show low redundancy (low internal trophic connections) and are considered to be more vulnerable to external perturbations which affect the trophic transfers between organisms (Baird et al., 2007; Scharler and Baird, 2005). This is consistent with the hypothesis on the limiting effect of simple community organisation and a high degree of disturbances on food chain length (Pimm, 1982; Post, 2002). However, identification which trophic interactions or which species are most critical to the stability of food webs in a system requires quantitative description of the flows of materials and energy between food web elements (Raffaelli, 2000). This modern energetic concept is based on estimates of biomass of all biocenotic compartments and turnover rates (rates of processes involved in organic matter trophic transformation) (Rooney et al., 2006) and uses energy (Joules) or elements (e.g. carbon, nitrogen) as the common currency for expressing the magnitude of particular connections. Another explanation of the causality of the observed relations between $H^{\prime}$ and $F C L$ can include availability and quality of resources in a system. More divergent and more available organic matter resources in a system are expected to support more energy pathways. 
1 maintenance of the heterogeneity of distinct energy channels. In case of the use of the stable

2 isotope approach, however, this theory might be biased by incomplete topological webs (the

3 lack of species) and imperfect definitions of trophic links. A higher resolution study allowing

4 for species-specific diet composition of more biocenotic components and trophic interaction within the entire food web, including small-bodied organisms and mobile predators (e.g. birds and mammals), is required to define the main directions of carbon flows in a more detailed manner.

\section{Conclusions}

Large-scale European study of food web structure within macrobenthic communities across a range of environmental parameters and biodiversity levels revealed important patterns of vertical organisation of trophic links. Food chain length increases with species richness and biodiversity (expressed by the Shannon-Wiener diversity index), highlighting the importance of taxonomical diversity for food web organisation. In species-rich and diverse communities energy is transferred through more trophic levels and along more numerous trophic pathways which utilise subsequently more diverse carbon sources in a system. Communities of a higher biodiversity level develop more complex trophic interactions which support high stability of the food web. In contrast, benthic communities with a small number of species support weak trophic connections and simple food web structure of a relatively short food chain length that makes them more susceptible to external perturbations.

\section{Acknowledgements}

This study was supported by the EU Network of Excellence "Marine Biodiversity and Ecosystem Functioning" (MarBEF; GOCE-CT-2003-505446). Prof Dr Peter M.J. Herman from Netherlands Institute of Ecology, Yerseke, the Netherlands is acknowledged for his valuable contribution to the manuscript and Joanna Legeżyńska, Emilia Trudnowska, Rafał Boehnke and Edyta Malec from Institute of Oceanology, Polish Academy of Sciences, Sopot, Poland for their assistance during taxonomic identification of Arctic invertebrates. Thanks are also due to Prof Dr Jan Marcin Węsławski from Institute of Oceanology, Polish Academy of Sciences Sopot, Poland for his help in organising the sampling expedition to the Arctic and Dr Darius Daunys from University of Klaipeda, Klaipeda, Lithuania for providing biodiversity data for the Curonian Lagoon. A.S. wishes to thank Gaelle Guillou from Littoral 
1 Environnement et Sociétés (LIENSs), Université de La Rochelle, La Rochelle, France, for his 2 assistance during stable isotope analyses. 


\section{References}

2

Baird, D., Asmus, H., Asmus, R., 2007. Trophic dynamics of eight intertidal communities of the Sylt-Rømø Bight ecosystem, Northern Wadden Sea. Marine Ecology Progress Series $351,25-41$.

Benedetti-Cecchi, L., 2000. Variance in ecological consumer-resource interactions. Nature 407, 370-374.

Bonsdorff, E., 2006. Zoobenthic diversity-gradients in the Baltic Sea: continuous post-glacial succession in a stressed ecosystem. Journal of Experimental Marine Biology and Ecology 330, 383-391.

Boutton, T.W., 1991. Stable carbon isotope ratios of natural materials; I. Sample preparation and mass spectrometric analysis. In: Coleman, D.C., Fry, B. (Eds.), Carbon Isotope Techniques. Academic Press, San Diego, pp. 155-171.

Briand, F., Cohen, J.E., 1987. Environmental correlates of food chain length. Science 238, 956-960.

Carlier, A., Riera, P., Amoroux, J.M., Bodiou, J.-Y., Grémare, A., 2007. Benthic trophic network in the Bay of Banyuls-sur-Mer (northwest Mediterranean, France): An assessment based on stable carbon and nitrogen isotopes analysis. Estuarine Coastal Shelf Science 72, 1-15.

Cohen, J.E., Briand, F., Newman, C.M., 1986. A stochastic theory of community food webs. III. Predicted and observed lengths of food chains. Proceedings of the Royal Society B 228, pp. 317-353.

Craig, H., 1953. The geochemistry of the stable carbon isotopes. Geochimica et Cosmochimica Acta 3, 53-92.

Créach, V., Schricke, M.T., Bertru, G., Mariotti, A., 1997. Stable isotope and gut analyses to determine feeding relationships in saltmarsh macroconsumers. Estuarine Coastal Shelf Science 44, 599-611.

Duffy, J.E., Cardinale, B.J., France, K.E., McIntyre, P.B., Thébault, E., Loreau, M., 2007. The functional role of biodiversity in food webs: Incorporating trophic complexity. Ecology Letters 10, 522-538.

Eleftheriou, A., McIntyre, A.D., 2005. Methods for the study of marine benthos. 3rd edition. Blackwell Science, Oxford, 418 pp. 
1 Elmgren, R., Hill, C., 1995. Ecosystem function at low biodiversity - the Baltic example. In: Ormond, R.F.G., Gage, J.D., Angel, M.V. (Eds.), Marine Biodiversity Patterns and Processes. Cambridge University Press, Cambridge. pp 319-336.

Elser, J.J., Hessen, D.O., 2005. Biosimplicity via stoichiometry: evolution of food-web structure and processes. In: Belgrano, A., Scharler, U.M., Dunne, J., Ulanowicz, R.E. (Eds.), Aquatic Food Webs. An Ecosystem Approach. Oxford University Press, New York, pp. 7-18.

Fredriksen, S., 2003. Food web studies in a Norway kelp forest based on stable isotope $\left(\delta^{13} \mathrm{C}\right.$ and $\delta^{15} \mathrm{~N}$ ) analysis. Marine Ecology Progress Series 260, 71-81.

Grall, J., Le Loch, F., Guyonnet, B., Riera, P., 2006. Community structure and food web based on stable isotopes $\left(\delta^{15} \mathrm{~N}\right.$ and $\left.\delta^{13} \mathrm{C}\right)$ analysis of a North Eastern Atlantic maerl bed. Journal of Experimental Marine Biology and Ecology 338, 1-15.

Hastings, A., Conrad, M., 1979. Length and evolutionary stability of food chains. Nature 140, 799-814.

Hecky, R.E., Hesslein, R.H., 1995. Contributions of benthic algae to lake food webs as revealed by stable isotope analysis. Journal of the North American Benthological Society 14, 631-653.

Heip, C., Warwick, R., d'Ozouville, L., 1998. European Marine and Polar Science (EmaPS). A European Science Plan on Marine Biodiversity. ESF (European Science Foundation) Marine Board Report, Strasbourg, 48 pp.

Herman, P.M.J., Middelburg, J. J., Widdows, J., Lucas, C.H., Heip, C.H.R., 2000. Stable isotopes as trophic tracers: Combining field sampling and manipulative labelling of food resources for macrobenthos. Marine Ecology Progress Series 204, 79-92

Hobson, K.A., Welch, H.E., 1992. Determination of trophic relationships within a high Arctic marine food web using $\delta^{13} \mathrm{C}$ and $\delta^{15} \mathrm{~N}$ analysis. Marine Ecology Progress Series 84, 9-18.

Hobson, K.A., Ambrose, Jr. W.G., Renaud, P.E., 1995. Sources of primary production, benthic-pelagic coupling, and trophic relationships within the Northeast Water Polynya: insights from $\delta^{13} \mathrm{C}$ and $\delta^{15} \mathrm{~N}$ analysis. Marine Ecology Progress Series 128, 1-10.

Kaehler, S., Pakhomov, E.A., McQuaid, C.D., 2000. Trophic structure of the marine food web at the Prince Edward Islands (Southern Ocean) determined by $\delta^{13} \mathrm{C}$ and $\delta^{15} \mathrm{~N}$ analysis. Marine Ecology Progress Series 208, 13-20.

Lebreton N., 2009, Analyse de la structure et du fonctionnement du reseau trophique d'un herbier par approche multi-traceurs: traçage isotopique naturel et profils acides gras. Thesis, University of La Rochelle, La Rochelle, France, 246 pp., (in French), unpublished 
1 Lesutienè, J., 2009. Food web of the Curonian Lagoon: organic matter sources and feeding of mysids. Ph.D. Thesis, Klaipeda University, Klaipeda, Lithuania, 145 pp., unpublished

Loreau, M., 2000. Biodiversity and ecosystem functioning: recent theoretical advances. Oikos 91, 3-17.

MacArthur, R.H., 1955. Fluctuation of animal populations and a measure of community stability. Ecology 36, 533-536.

Martinez del Rio, C., 2007. Isotopic ecology. In: Karasov, W.H., Martinez del Rio, C. (Eds.), Physiological Ecology: How Animals Process Energy, Nutrients and Toxins. Princeton University Press, Princeton, pp. 433-478.

McCutchan, Jr. J.H., Lewis Jr., W.M., Kendall, C., McGrath, C.C., 2003. Variation in trophic shift for stable isotope ratios of carbon, nitrogen and sulfur. Oikos 102, 378-390.

Monbet, Y., 1992. Control of phytoplankton biomass in estuaries: A comparative analysis of microtidal and macrotidal estuaries. Estuaries 15, 563-571.

Olive, P.J.W., Pinnegar, J.K., Polunin, N.V.C., Richards, G., Welch, R., 2003. Isotope trophic-step fractionation: a dynamic equilibrium model. Journal of Animal Ecology 72, 608-617.

Ostrom, P.H., Fry, B., 1993. Sources and cycling of organic matter within modern and prehistoric food webs. In: Engel, M.H., Macko, S.A. (Eds.), Organic Geochemistry: Principles and Applications. Plenum Press, New York, pp. 785-797.

Parker, P.L., 1964. The biogeochemistry of the stable isotopes of carbon in a marine bay. Geochimica et Cosmochimica Acta 28, 1155-1164.

Pielou, E.C., 1966. The measurement of diversity in different types of biological collections. Journal of Theoretical Biology 13, 131-144.

Pimm, S.L., 1982. Food Webs. Chapman \& Hall, London, 219 pp.

Post, D.M., 2002. Using stable isotopes to estimate trophic positions: models, methods, and assumptions. Ecology 83, 703-718.

Raffaelli, D., 2000. Trends in research on shallow water food webs. Journal of Experimental Marine Biology and Ecology 250, 223-232.

Renaud, P.E., Ambrose, W.G., Vanreusel, A., Clough, L.M., 2006. Nematode and macrofaunal diversity in central Arctic Ocean benthos. Journal of Experimental Biology and Ecology 330, 297-306.

Renaud, P.E., Webb, T.J., Bjørgesæter, A., Karakassis, I., Kędra, M., Kendall, M.A., Labrune, C., Lampadariou, N., Somerfield, P.J., Włodarska-Kowalczuk, M., Vanden Berghe, E., Claus, S., Aleffi, I.F., Amouroux, J.M., Bryne, K.H., Cochrane, S.J., Dahle, S., Degraer, 
S., Denisenko, S.G., Deprez, T., Dounas, C., Fleischer, D., Gil, J., Grémare, A., Janas, U., Mackie, A.S.Y., Palerud, R., Rumohr, H., Sardá, R., Speybroeck, J., Taboada, S., Van Hoey, G., Węsławski, J.M., Whomersley, P., Zettler, M.L., 2009. Continental-scale patterns in benthic invertebrate diversity: insights from the MacroBen database. Marine Ecology Progress Series 382, 239-252.

Riera, P., 1998. $\delta^{15} \mathrm{~N}$ of organic matter sources and benthic invertebrates along an estuarine gradient in Marennes-Oléron Bay (France): implications for the study of trophic structure. Marine Ecology Progress Series 166, 143-150.

Riera, P., Stal, L.S., Nieuwenhuize, J., Richard, P., Blanchard, G., Gentil, F., 1999. Determination of food sources for benthic invertebrates in a salt marsh (Aiguillon Bay, France) by carbon and nitrogen stable isotopes: importance of locally produced sources. Marine Ecology Progress Series 187, 301-307.

Rooney, N., McCann, K., Gellner, G., Moore, J.C., 2006. Structural asymmetry and the stability of diverse food webs. Nature 442, 265-269.

Scharler, U.M., Baird, D., 2005. A comparison of selected ecosystem attributes of three South African estuaries with different freshwater inflow regimes, using network analysis. Journal of Marine Systems 56, 283-308.

Shannon, C.E., Weaver, W., 1963. The Mathematical Theory of Communication. University of Illinois Press, Urbana, 117 pp.

Sokal, R.R., Rohlf, F.J., 1995. Biometry. W.H. Freeman and Company, New York, 887 pp.

Sokołowski, A., 2009, Tracing the flow of organic matter based upon dual stable isotope technique, and trophic transfer of trace metals in benthic food web of the Gulf of Gdańsk (the southern Baltic Sea). Wydawnictwo Uniwersytetu Gdańskiego, Gdańsk, 213 pp.

Tamelander, T., Renaud, P.E., Hop, H., Carroll, M.L., Ambrose Jr., W.G., Hobson, K., 2006. Trophic relationships and pelagic-benthic coupling during summer in the Barents Sea Marginal Ice Zone revealed by stable carbon and nitrogen isotope measurements. Marine Ecology Progress Series 310, 33-46.

Tamelander, T., Reigstad, M., Hop, H., Carroll, M., Wassmann, P., 2008. Pelagic and sympagic contribution of organic matter to zooplankton and vertical export in the Barents Sea marginal ice zone. Deep-Sea Research 55, 2330-2339.

Vander Zanden, M.J., Rasmussen, J.B., 2001. Variation in $\delta^{15} \mathrm{~N}$ and $\delta^{13} \mathrm{C}$ trophic fractionation: implications for aquatic food web studies. Limnology and Oceanography 46, 2061-2066.

Vander Zanden, M.J., Fetzer, W.W., 2007. Global patterns of aquatic food chain length. Oikos $116,1378-1388$. 
1 Vander Zanden, M.J., Shuter, B.J., Laster, N., Rasmussen, J.B., 1999. Patterns of food chain length in lakes: stable isotope study. American Naturalist 154, 406-416.

3 Vanderklift, M.A., Ponsard, S., 2003. Sources of variation in consumer diet $\delta^{15} \mathrm{~N}$ enrichment: a 4 meta analysis. Oecologia 136, 169-182.

Warwick, R.M., Emblow, C., Féral, J.P., Hummel, H., van Avesaath, P., Heip, C., 2003. European Marine Biodiversity Research Sites. NIOO-CEME, Yerseke, 136 pp.

Włodarska-Kowalczuk, M., Sicinski, J., Gromisz, S., Kendall, M.A., Dahle, S., 2007. Similar soft-bottom polychaete diversity in Arctic and Antarctic marine inlets. Marine Biology $151,607-616$.

Wołowicz, M., Sokołowski, A., Lasota, R., 2007. Estuaries-a biological point of view. Oceanological and Hydrobiological Studies 36, 113-130. 
Table 1. Characteristics of sampling sites used for comparative analyses of macrobenthic community structure and food web attributes in different ecosystems.

\begin{tabular}{|c|c|c|c|c|c|c|c|c|c|c|c|}
\hline \multirow{2}{*}{ Water-basin } & \multirow{2}{*}{ Location } & \multirow{2}{*}{ Site } & \multirow{2}{*}{ Site abbreviation } & \multicolumn{2}{|c|}{ Geographic position } & \multirow[t]{2}{*}{ Salinity } & \multirow[t]{2}{*}{ Tides* } & \multicolumn{2}{|c|}{ Sampling } & \multirow{2}{*}{ Type of habitat } & \multirow{2}{*}{$\begin{array}{c}\text { BIOMARE } \\
\text { site }\end{array}$} \\
\hline & & & & Latitude & Longitude & & & season & $\operatorname{depth}[\mathrm{m}]$ & & \\
\hline North Atlantic & Hornsund fjord & Hornsund & Hornsund & $77^{\circ} 02.36^{\prime} \mathrm{N}$ & $16^{\circ} 00.62^{\prime} \mathrm{E}$ & 29.4 & + & summer & 60.0 & muddy sand & ATBI, NFS \\
\hline \multirow[t]{2}{*}{ Barents Sea } & open water, & Barents Sea, St 4 & St 4 & $77^{\circ} 01.09^{\prime} \mathrm{N}$ & $29^{\circ} 29.19^{\prime} \mathrm{E}$ & 35.0 & + & summer & 222.0 & muddy sand & \\
\hline & Marginal Ice Zone & Barents Sea, St 16 & St 16 & $77^{\circ} 05.20^{\prime} \mathrm{N}$ & $28^{\circ} 33.00^{\prime} \mathrm{E}$ & 35.0 & + & spring & 206.0 & muddy sand & \\
\hline \multirow[t]{4}{*}{ Baltic Sea } & the Gulf of Gdańsk & Puck Bay & Puck & $54^{\circ} 41.05^{\prime} \mathrm{N}$ & $18^{\circ} 31.75^{\prime} \mathrm{E}$ & $6.2-7.0$ & - & spring & 7.0 & sandy bottom & LTBR \\
\hline & & site Gdansk & Gdansk & $54^{\circ} 37.50^{\prime} \mathrm{N}$ & $18^{\circ} 37.50^{\prime} \mathrm{E}$ & $6.5-7.2$ & - & spring & 30.0 & muddy bottom & \\
\hline & Curonian Lagoon & $\begin{array}{l}\text { Curonian Lagoon- } \\
\text { mussel bed }\end{array}$ & Curonian-mb & $55^{\circ} 21.02^{\prime} \mathrm{N}$ & $21^{\circ} 09.58^{\prime} \mathrm{E}$ & $0.0-7.2$ & - & summer & $0.7-3.4$ & mussel beds & NFS \\
\hline & & $\begin{array}{l}\text { Curonian Lagoon- } \\
\text { bare sediments }\end{array}$ & Curonian-bs & $55^{\circ} 31.80^{\prime} \mathrm{N}$ & $21^{\circ} 07.46^{\prime} \mathrm{E}$ & $0.0-7.2$ & - & summer & $0.7-2.3$ & bare sediments & \\
\hline \multirow[t]{2}{*}{ North Sea } & Sylt-Rømø Bight & Sylt-Rømø Bight & Sylt-Rømø & $55^{\circ} 00^{\prime} \mathrm{N}$ & $8^{\circ} 25^{\prime} \mathrm{E}$ & $28.0-32.0$ & + & spring & $4.2 * *$ & sandy bottom & LTBR \\
\hline & Westerschelde & Molenplaat & Molenplaat & $51^{\circ} 26^{\prime} \mathrm{N}$ & $3^{\circ} 57^{\prime} \mathrm{E}$ & $20.0-25.0$ & + & autumn & $0 * *$ & mudflat & \\
\hline \multirow[t]{3}{*}{ Bay of Biscay } & Marennes-Oleron & Brouage & Brouage & $45^{\circ} 54.88^{\prime} \mathrm{N}$ & $1^{\circ} 06.05^{\prime} \mathrm{W}$ & $25.0-35.0$ & + & autumn & 0 & mudflat & \\
\hline & Bay & $\begin{array}{l}\text { Oleron Zostera bed- } \\
\text { lower flat }\end{array}$ & Oleron Zostera-lf & $45^{\circ} 55.05^{\prime} \mathrm{N}$ & $1^{\circ} 12.25^{\prime} \mathrm{W}$ & $28.0-34.5$ & + & spring & 0 & $\begin{array}{l}\text { Zostera bed- } \\
\text { lower flat }\end{array}$ & \\
\hline & & $\begin{array}{l}\text { Oleron Zostera bed- } \\
\text { upper flat }\end{array}$ & Oleron Zostera-uf & $45^{\circ} 54.63^{\prime} \mathrm{N}$ & $1^{\circ} 12.88^{\prime} \mathrm{W}$ & $28.0-34.5$ & + & spring & 0 & $\begin{array}{c}\text { Zostera bed- } \\
\text { upper flat }\end{array}$ & \\
\hline $\begin{array}{l}\text { Mediterranean } \\
\text { Sea }\end{array}$ & $\begin{array}{l}\text { Bay of Banyuls-sur- } \\
\text { Mer }\end{array}$ & Banyuls & Banyuls & $42^{\circ} 29.77^{\prime} \mathrm{N}$ & $03^{\circ} 8.76^{\prime} \mathrm{E}$ & 37.2 & - & spring & $17.4-34.0$ & $\begin{array}{c}\text { well-sorted fine } \\
\text { sand }\end{array}$ & LTBR \\
\hline
\end{tabular}

ATBI - All Taxon Biodiversity Inventory site, NFS - Normal Focal Site, LTBR - Long-Term Biodiversity Research site 
Table 2. Characteristics of macrobenthic communities at sampling sites in European waters (in brackets - percentage contribution of a given class to the total number of species). Classes are arranged in order of a decreasing total number of species.

\begin{tabular}{|c|c|c|c|c|c|c|c|c|c|c|c|}
\hline \multirow{3}{*}{ Site } & \multirow{3}{*}{$\begin{array}{l}\text { Total abundance } \\
\text { (ind. } \mathrm{m}^{-2} \text { ) }\end{array}$} & \multicolumn{6}{|c|}{ No species } & \multirow{3}{*}{$\begin{array}{l}\text { Total no } \\
\text { classes }\end{array}$} & \multirow{3}{*}{$H^{\prime}$} & \multirow{3}{*}{$J$} & \multirow{3}{*}{ source } \\
\hline & & \multicolumn{6}{|c|}{ Dominating class } & & & & \\
\hline & & total & Polychaeta & Crustacea & Bivalvia & Gastropoda & Clitellata & & & & \\
\hline Hornsund & 6040 & 48 & $20(41.7)$ & $3(6.3)$ & $13(27.1)$ & $4(8.3)$ & & 7 & 2.35 & 0.61 & own data \\
\hline St 4 & 5550 & 166 & $69(41.6)$ & $46(27.7)$ & $11(6.6)$ & $7(4.2)$ & & 21 & 3.26 & 0.64 & own data \\
\hline St 16 & 5328 & 166 & $71(42.8)$ & $44(26.1)$ & $11(6.6)$ & $9(5.4)$ & & 19 & 1.61 & 0.32 & own data \\
\hline Puck & 1133 & 11 & $2(18.2)$ & $2(18.2)$ & $4(36.4)$ & & & 4 & 1.46 & 0,66 & $\mathrm{a}$ \\
\hline Gdansk & 63 & 3 & $1(33.3)$ & & $1(33.3)$ & & & 3 & 0.71 & 0.64 & a \\
\hline Curonian-mb & 5014 & 29 & $2(6.9)$ & $5(17.2)$ & $4(13.8)$ & $6(20.7)$ & $5(17.2)$ & 10 & 2.02 & 0.60 & $\mathrm{~b}$ \\
\hline Curonian-bs & 3913 & 23 & $2(8.7)$ & $4(17.4)$ & $4(17.4)$ & $3(13.0)$ & $4(17.4)$ & 10 & 1.76 & 0.56 & $\mathrm{~b}$ \\
\hline Sylt-Rømø & 71704 & 25 & $11(44.0)$ & $6(24.0)$ & $4(16.0)$ & $2(8.0)$ & & 6 & 1.07 & 0.33 & own data \\
\hline Molenplaat & 11069 & 19 & $8(42.1)$ & $5(26.3)$ & $3(15.8)$ & $1(5.3)$ & & 6 & 2.15 & 0.73 & $\mathrm{c}$ \\
\hline Brouage & 34517 & 30 & $11(36.7)$ & $4(13.3)$ & $9(30.0)$ & $3(10.0)$ & & 7 & 1.57 & 0.46 & own data \\
\hline Oleron Zostera-lf & 7152 & 27 & $10(37.0)$ & $6(22.2)$ & $5(18.5)$ & $3(11.1)$ & & 7 & 0.49 & 0.15 & own data \\
\hline Oleron Zostera-uf & 15701 & 32 & $11(34.4)$ & $4(12.5)$ & $9(28.1)$ & $2(6.3)$ & & 9 & 0.26 & 0.08 & own data \\
\hline Banyuls & 10928 & 128 & $57(44.5)$ & $21(16.4)$ & 27 (21.1) & $5(3.9)$ & & 12 & 2.86 & 0.59 & own data \\
\hline
\end{tabular}

a) Sokołowski, 2009 b) Daunys, unpubl. data c) Herman, unpubl. data 
Table 3. Number of species analysed for carbon and nitrogen stable isotope composition and their percentage contribution to species richness and the total abundance of benthic faunal communities along with selected features of food webs in different systems of European waters.

\begin{tabular}{|c|c|c|c|c|c|c|c|}
\hline \multirow{2}{*}{ site } & \multirow{2}{*}{$\begin{array}{c}\text { No } \\
\text { species }\end{array}$} & \multicolumn{2}{|c|}{ Contribution to } & \multirow{2}{*}{$\begin{array}{c}\text { Nitrogen isotope } \\
\text { baseline }\end{array}$} & \multirow{2}{*}{$F C L^{*}$} & \multirow{2}{*}{$\begin{array}{c}\text { Principal organic } \\
\text { matter source }\end{array}$} & \multirow[t]{2}{*}{ source } \\
\hline & & species richness & abundance & & & & \\
\hline Puck & 14 & 66.7 & 78.8 & 8.4 & 3.64 & SPOM, SOM & $\mathrm{a}$ \\
\hline Gdansk & 3 & 33.3 & 73.7 & 9.4 & 3.08 & SPOM, SOM & $\mathrm{a}$ \\
\hline Curonian-mb & 18 & 24.1 & 72.5 & 7.0 & 4.86 & SPOM & $\mathrm{b}$ \\
\hline Curonian-bs & 12 & 17.4 & 47.1 & 7.2 & 3.92 & SPOM & b \\
\hline Sylt-Rømø & 28 & 60.0 & 84.6 & 10.9 & 3.65 & SPOM, MPB**, macroalgae, vascular plants & own data \\
\hline Molenplaat & 16 & 63.2 & 87.4 & 16.9 & 4.12 & SPOM, SOM & $\mathrm{c}$ \\
\hline Brouage & 32 & 60.0 & 98.7 & 8.3 & 4.12 & SPOM, SOM, MPB & this study \\
\hline Oleron Zostera-lf & 30 & 48.1 & 97.7 & 6.8 & 3.64 & MPB, Zostera detritus & $\mathrm{d}$ \\
\hline Oleron Zostera-uf & 30 & 40.6 & 98.9 & 7.2 & 3.47 & MPB, SOM, Zostera detritus & $\mathrm{d}$ \\
\hline Banyuls & 121 & 20.3 & 14.6 & 2.7 & 4.75 & SPOM, SOM & $\mathrm{e}$ \\
\hline St 4 & 29 & 8.5 & 6.2 & 6.6 & 4.30 & iceSPOM & $f, g$ \\
\hline St 16 & 29 & 4.2 & 1.3 & 9.6 & 4.38 & iceSPOM, SPOM & $\mathrm{f}, \mathrm{g}$ \\
\hline Hornsund & 21 & 22.9 & 58.4 & 6.0 & 4.46 & SPOM, SOM & this study \\
\hline
\end{tabular}

* FLC - food chain length, ** MPB - microphytobenthos.

a) Sokołowski, 2009 b) Lesutienè, 2009 c) Herman et al., 2000 d) Lebreton, 2009 e) Carlier et al., 2007 f) Tamelander et al., 2006 g) Tamelander et al., 2008 
Figure captions

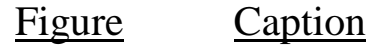

Fig. 1. Location of sampling sites

Fig. 2. Abundance of macrobenthic fauna divided into dominating classes at 13 sites in European waters (* Med - Mediterranean Sea, NA - North Atlantic)

Fig. 3. $\quad \delta^{13} \mathrm{C}$ and $\delta^{15} \mathrm{~N}$ of organic matter sources across all sites in different European waters.

Fig. 4. $\quad \delta^{13} \mathrm{C}$ and $\delta^{15} \mathrm{~N}$ of organic matter sources and benthic fauna in different European waters (mind different scales).

Fig. 5. Distribution of a number of species among trophic levels within macrobenthic community in different European waters (* Med - Mediterranean Sea, NA North Atlantic). 


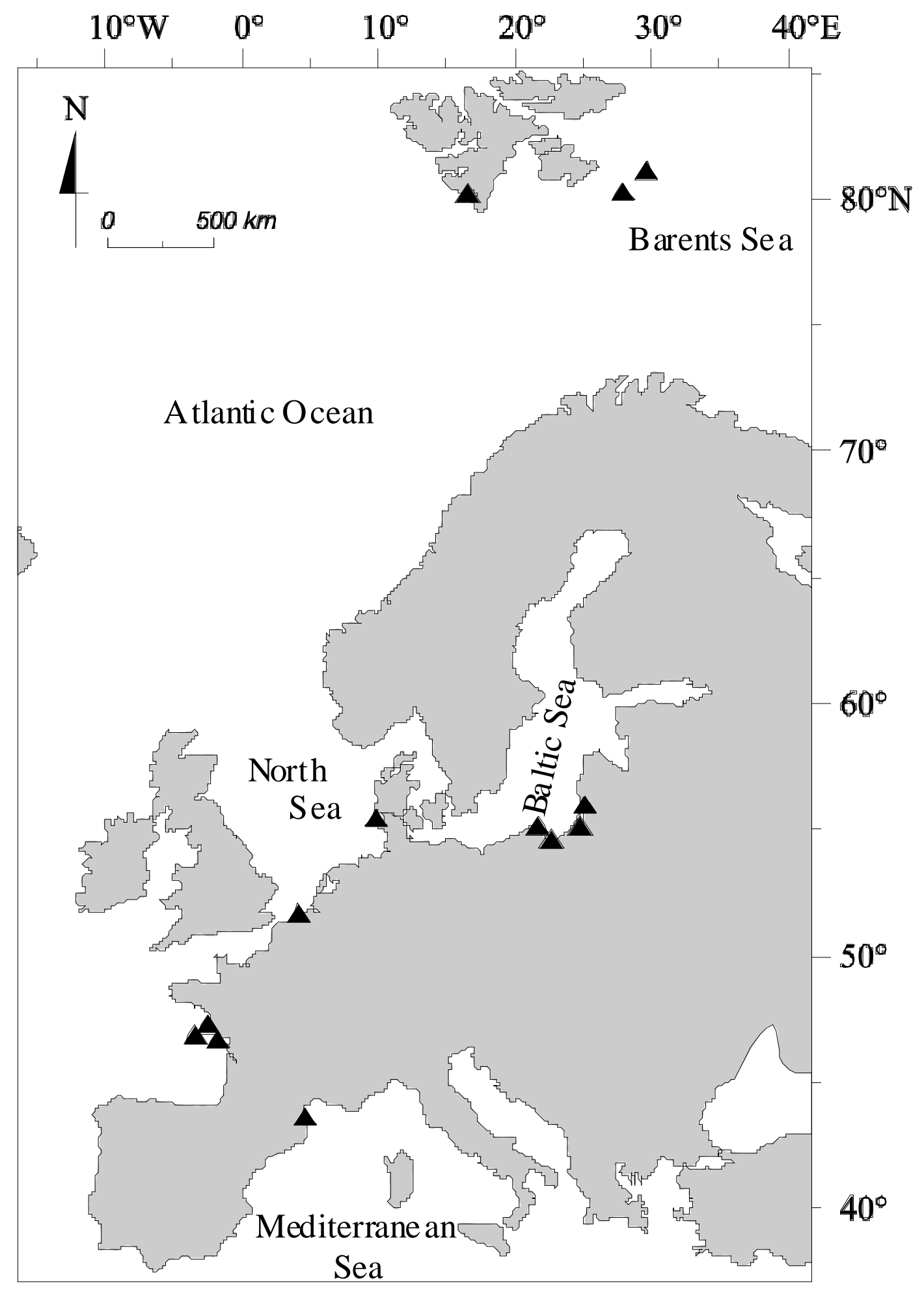

Fig. 1. 


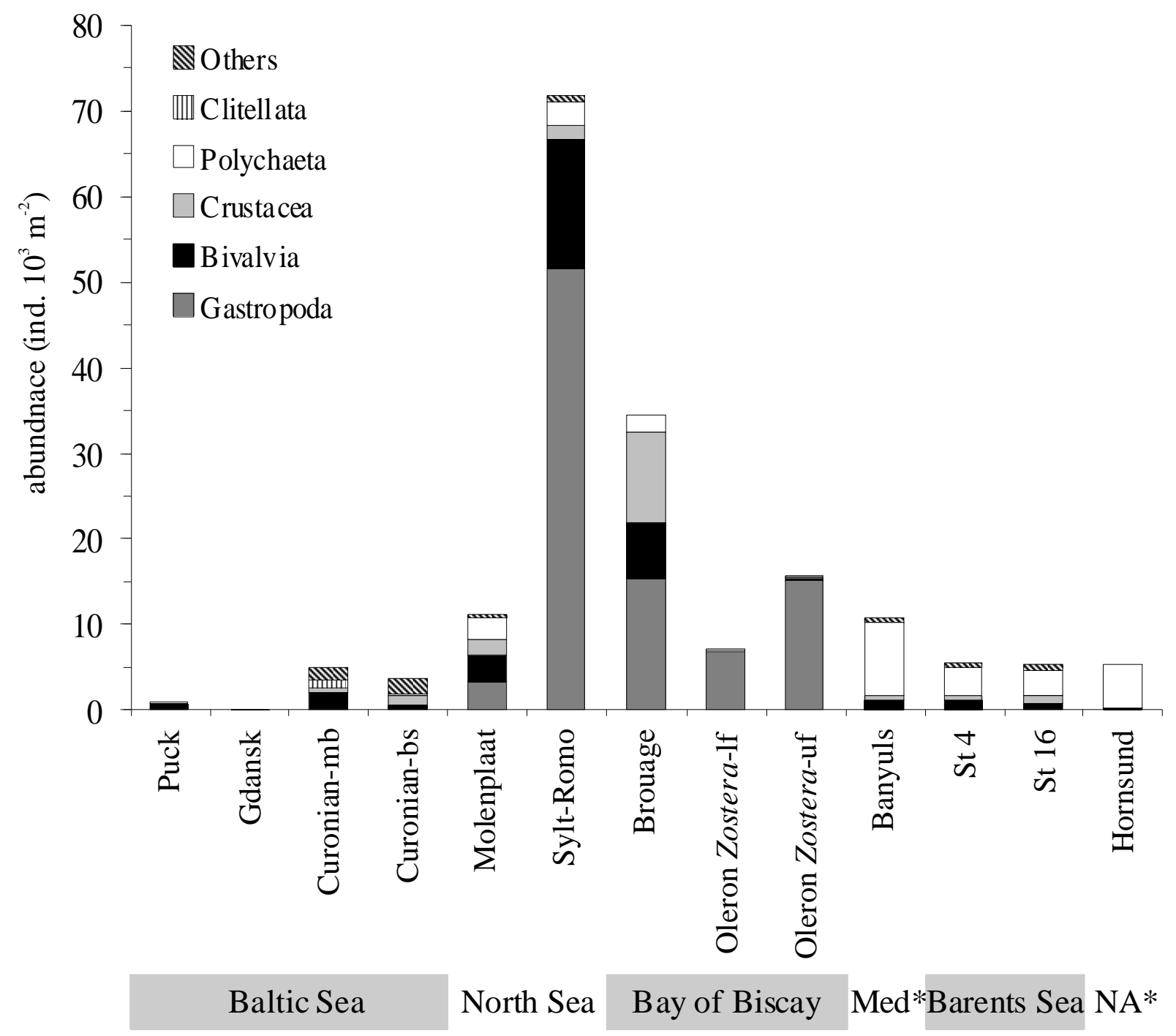

Fig. 2. 


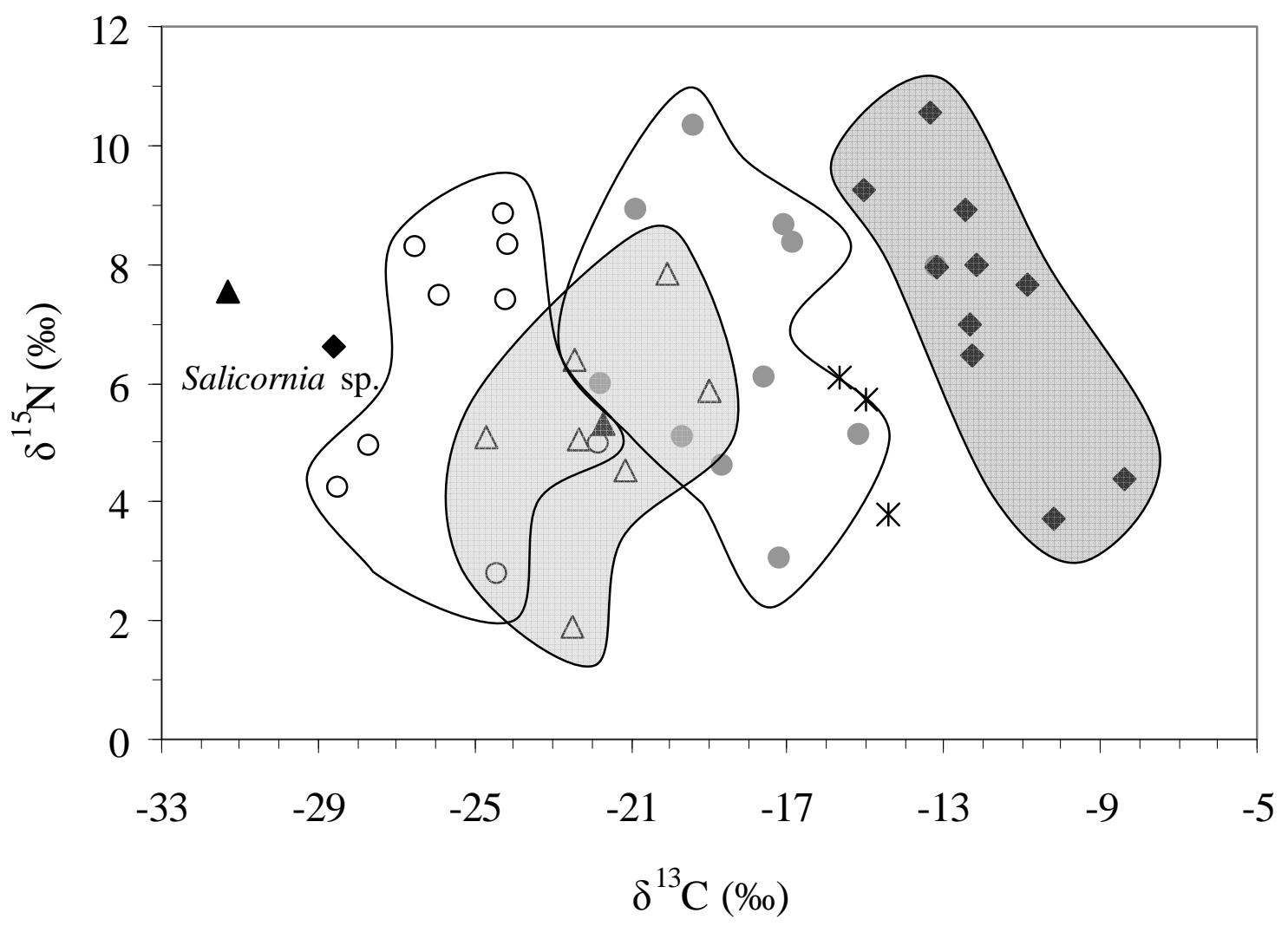

$\triangle \mathrm{SOM} \circ \mathrm{POM} \triangle \mathrm{POMriv} * \mathrm{MPB} \bullet$ macroalgae $\bullet$ vascular plants

Fig. 3. 

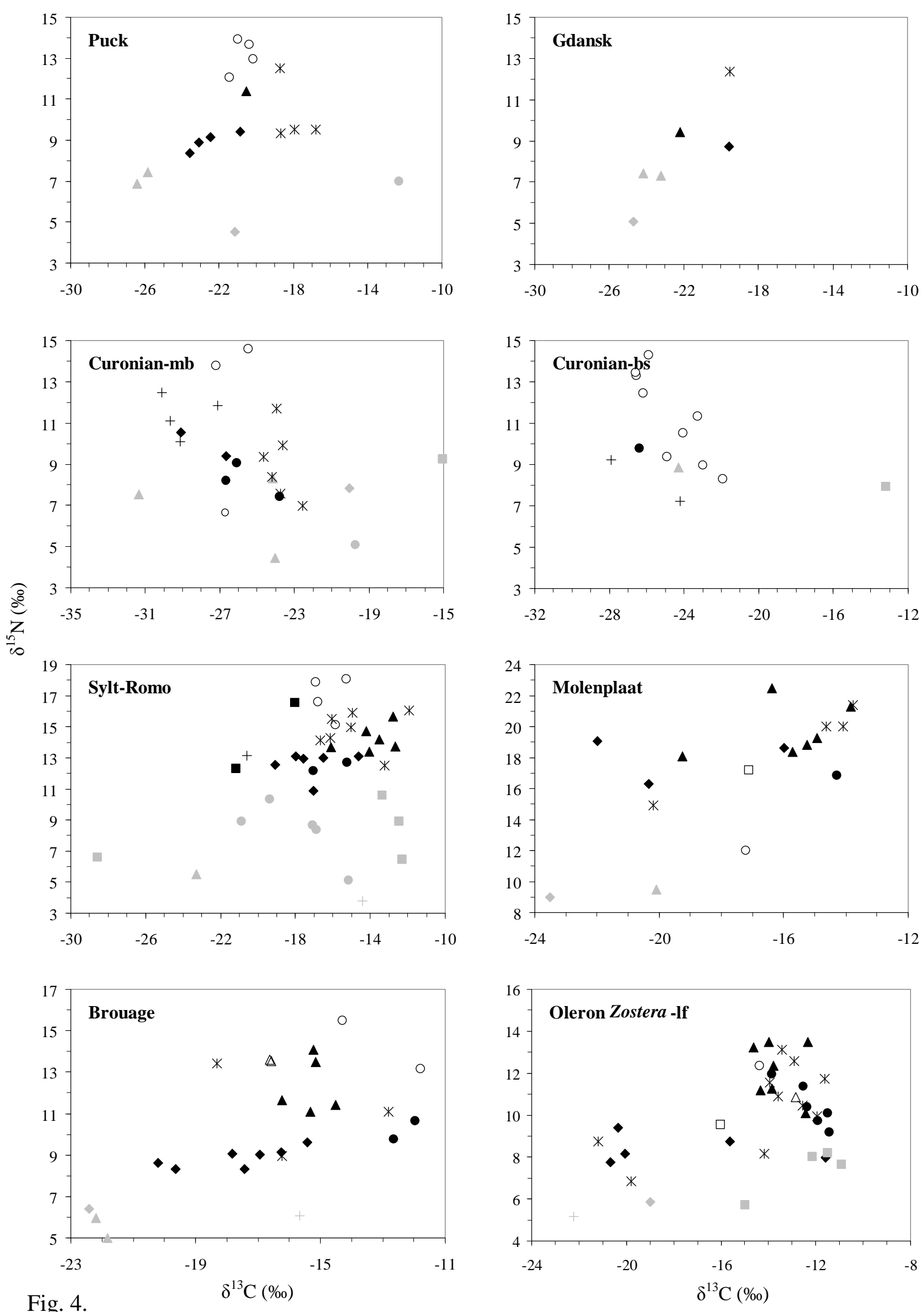

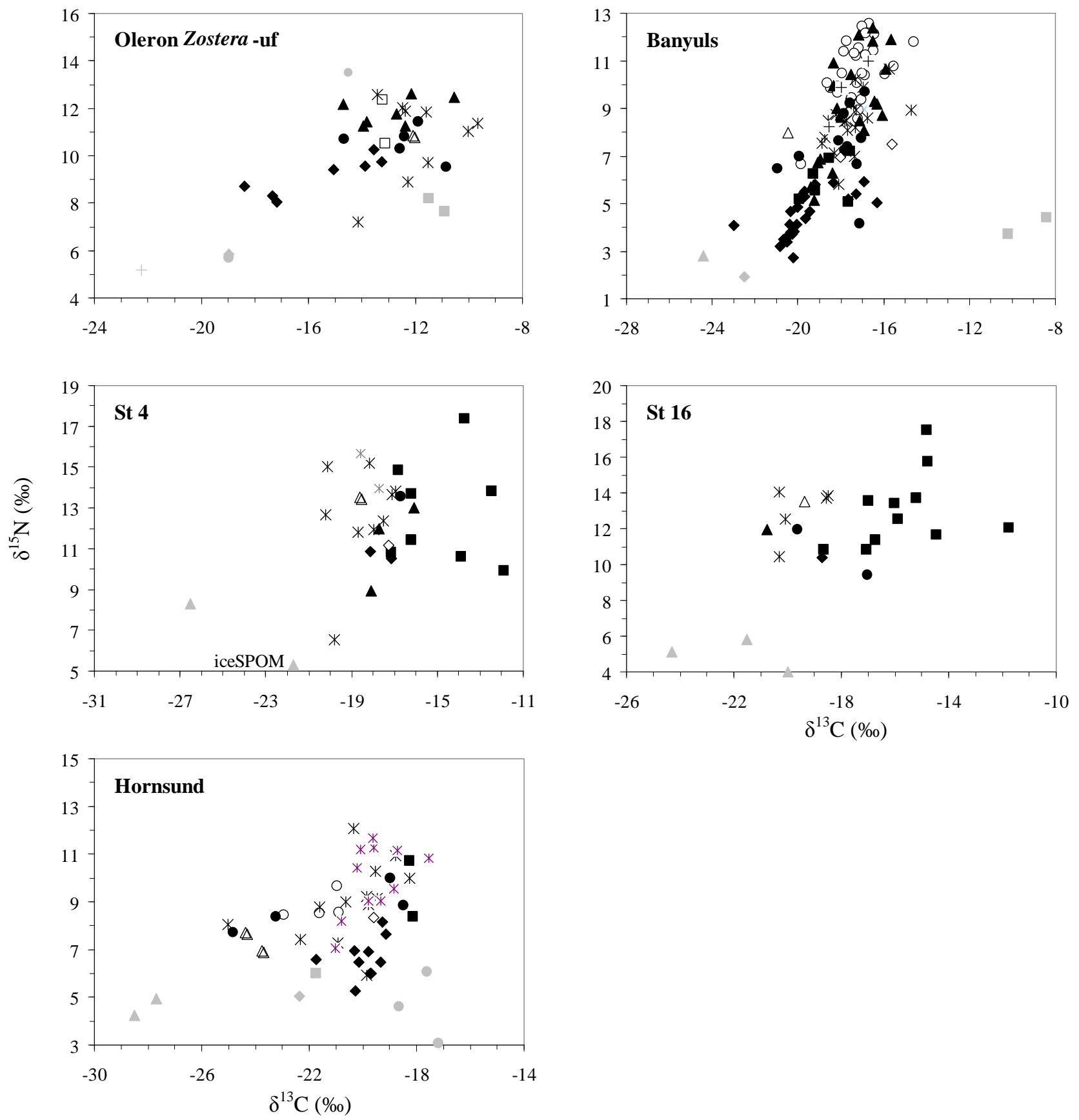

Organic matter sources

$\rightarrow \mathrm{SOM} \triangle \mathrm{SPOM} \bigcirc$ macroalgae $\square$ vascular plants
+ microphytobenthos

Benthic fauna

- Gastropoda $*$ Crustacea $\Delta$ Polychaeta $\bullet$ Bivalvia

$\triangle$ Cnidaria $\diamond$ Sipuncula $\square$ Nemertea $\quad$ Pisces

- Asteroidea/Ophiuroidea/Holothuroirdea

+ Other

Fig. 4. cont. 


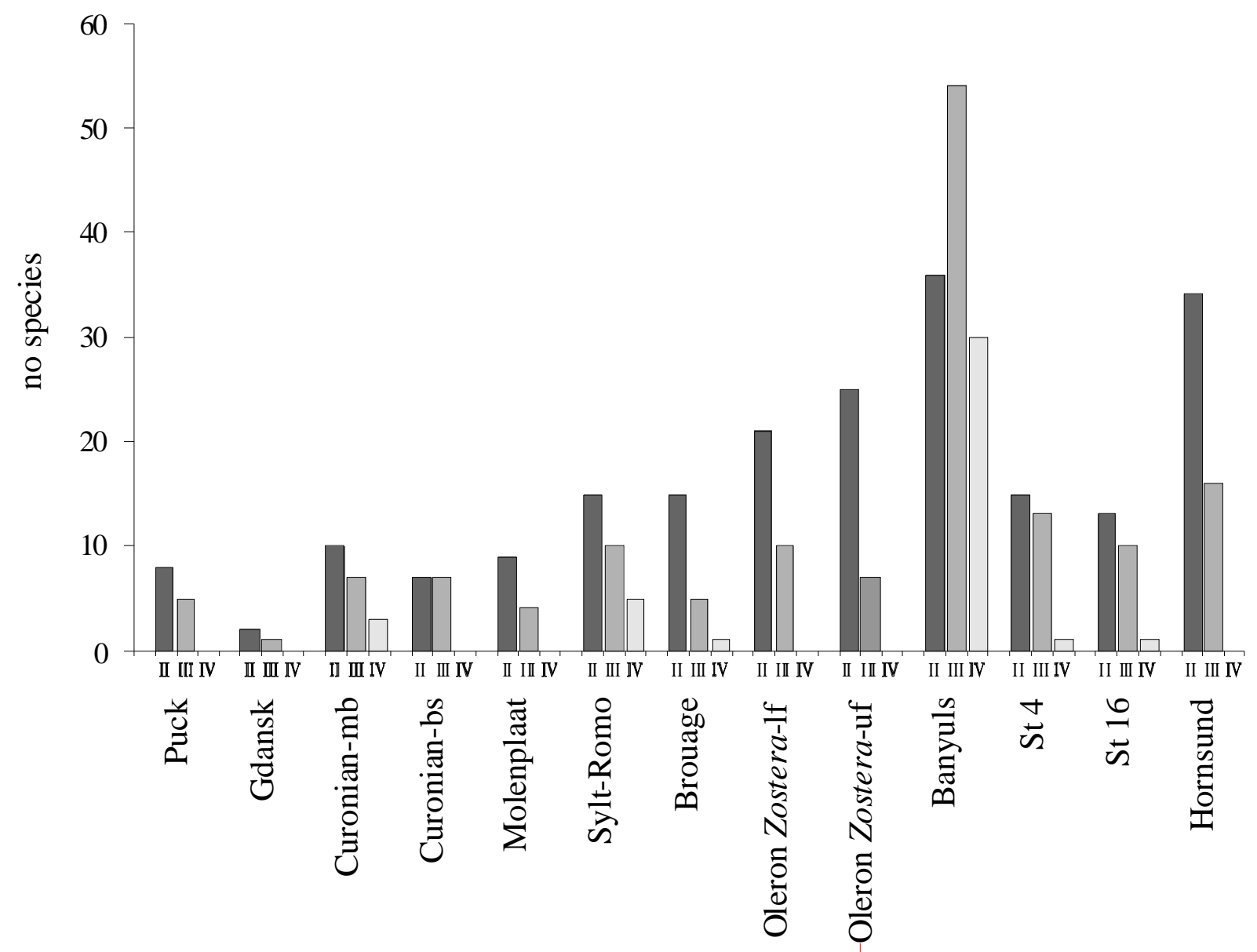

Baltic Sea North Sea Bay of Biscay Med*Barents Sea NA*

Fig. 5. 